\title{
Analisis Perubahan Penggunaan Lahan Menggunakan Metode NDVI (Normalized Difference Vegetation Index) pada Kecamatan Natar, Kabupaten Lampung Selatan
}

\author{
Fattur Rachman ${ }^{1 *}$, Winih Sekaringtyas Ramadhani ${ }^{1}$, Ali Rahmat ${ }^{2}$ \\ ${ }^{1}$ Jurusan Ilmu Tanah, Fakultas Pertanian, Universitas Lampung. Jl. Sumantri Brojonegoro, Bandar Lampung, 35145, Lampung, Indonesia. \\ ${ }^{2}$ Pusat Penelitian Limnologi, Lembaga Ilmu Pengetahuan Indonesia. Jl. Raya Jakarta-Bogor Km 46, Bogor, 16911, Jawa Barat, Indonesia.
}

DOI: https://doi.org/10.29303/ujcs.v2i1.22

\section{Article Info}

Received: January 24th, $2021 \quad$ Revised: February 28th, $2021 \quad$ Accepted: March 10 1021

\begin{abstract}
ABSTRAK: Kecamatan Natar merupakan salah satu Kecamatan yang berada di Kabupaten Lampung Selatan yang memiliki luasan 213,77 km2 atau sekitar 21.377 Ha. Pada Sektor Pertanian, sebagian besar lahan di Kecamatan Natar didominasi oleh tanaman jagung dan padi sawah. Penelitian ini bertujuan untuk mengetahui perubahan penggunaan lahan tahun 2002, dan 2019 pada Kecamatan Natar, Kabupaten Lampung Selatan. Penelitian ini menggunakan Citra dari landsat 7 dan 8 yang diolah dalam metode NDVI (Normalized Difference Vegetation Index) dengan rumus "NDVI = (NIRRED)/(NIR+RED)". Setelah dilakukannya pengolahan data kemudian dilakukannya pengamatan lapang terhadap 30 titik sampel yang menyebar secara merata di seluruh Kecamatan Natar. Pada Penelitian ini didapatkan hasil bahwa perubahan lahan menjadi lahan terbuka meningkat setiap tahunnya, di sisi lain luas lahan dengan tingkat kerapatan vegetasi rendah sampai sedang menurun setiap tahunnya. Pada pengamatan lapangan didapatkan penggunaan lahan yang bervariasi mulai dari pemukiman, pasar, serta berbagai penggunaan untuk lahan pertanian dan perkebunan. Lahan terbuka di Kecamatan Natar pada tahun 2019 meningkat sebanyak 32,7\% dari tahun 2002, sebaliknya lahan vegetasi rendah dan sedang menurun masing masing 32,5\% dan 12,5\% sejak tahun 2002. Pemerintah harus mengetatkan peraturan lingkungan terkait lahan lahan yang boleh dialihfungsikan maupun yang tidak. Jika pertumbuhan penduduk menjadi tidak terkendali, alih fungsi lahan pertanian meningkat, maka akan mustahil Indonesia dapat mewujudkan ketahanan pangan nasional.

Kata kunci: Natar; jagung; lahan.
\end{abstract}

Abstract: Natar District is one of the districts in South Lampung Regency which has an area of 213.77 km2 or around 21,377 HA. In the agricultural sector, most of the land in Natar District is dominated by maize and paddy fields. This study aims to determine changes in land use in 2002, 2009 and 2019 in Natar District, South Lampung Regency. This study uses imagery from Landsat 7 and 8 processed in the NDVI (Normalized Difference Vegetation Index) method with the formula "NDVI = (NIR-RED) / (NIR + RED)". After processing the data, field observations were made to 30 sample points which were spread evenly throughout the Natar District. In this study, the results showed that land conversion to open land increased every year, on the other hand the area of land with low to moderate vegetation density decreased every year. In field observations, it was found that various land uses ranging from settlements, markets, and various uses for agricultural and plantation land. Open land in Natar District in 2019 increased by 32.7\% from 2002, on the other hand, low and moderate vegetation land has decreased by $32.5 \%$ and $12.5 \%$ respectively since 2002 . The government must tighten environmental regulations regarding land which can be converted or not. If population growth becomes uncontrolled, the conversion of agricultural land functions increases, it will be impossible for Indonesia to realize national food security.

Keywords: Natar; maize; land.

Citation: Rachman, F. (2021). Analisis Perubahan Penggunaan Lahan Menggunakan Metode NDVI (Normalized Difference Vegetation Index) pada Kecamatan Natar, Kabupaten Lampung Selatan. Unram Journal of Community Service, 2(1), 17-23. doi:https://doi.org/10.29303/ujcs.v2i1.22

\footnotetext{
* Email: fatturrachman99@gmail.com
} 


\section{Pendahuluan}

Kecamatan Natar merupakan kecamatan yang memiliki wilayah paling luas di Kabupaten Lampung Selatan. Menurut Badan Pusat Statistik (2015), dari 200.701 Ha luasan wilayah Kabupaten Lampung Selatan, daerah seluas 21.377 Ha masuk ke dalam Kecamatan Natar. Menurut UPTD Pelaksanaan Penyuluhan Pertanian Kecamatan Natar dalam Purnomo (2018), dari total luasan tersebut $5.055 \mathrm{Ha}$ merupakan lahan sawah, sedangkan sisanya yaitu 16.322 Ha merupakan lahan untuk penggunaan selain sawah. Dari total $5.055 \mathrm{Ha}$, sebanyak $4.643 \mathrm{Ha}$ merupakan sawah non irigasi. Hanya sekitar $412 \mathrm{Ha}$ yang merupakan sawah yang memiliki irigasi dan tidak mengandalkan tadah hujan.

Badan Pusat Statistik (2015) lebih lanjut melaporkan bahwa laju pertumbuhan penduduk di Kecamatan Natar tiap tahunnya sekitar 2,82\% serta terus meningkat setiap tahunnya. Pertumbuhan penduduk yang semakin meningkat setiap tahunnya akan mendorong alih fungsi lahan dari lahan pertanian dan perkebunan menjadi pemukiman baru. Jika pertumbuhan penduduk ini semakin besar dan alih fungsi lahan tidak dapat dicegah, maka akan semakin banyak lahan pertanian dan perkebunan yang berubah menjadi pemukiman baru.

Pusat Penerbangan Provinsi Lampung, Bandara Raden Inten II dan salah satu gerbang masuk tol Lampung terdapat di Kecamatan Natar. Selain itu, Kecamatan Natar adalah salah satu Kecamatan yang berbatasan dengan Pusat Kota Bandar Lampung namun harga tanah dan bangunan di Natar jauh lebih murah dari tanah di Bandar Lampung. Kemudahan Akses ini menyebabkan banyak masyarakat yang membeli tanah di Kecamatan Natar dan membentuk pemukiman baru. Penambahan penduduk akibat migrasi masyarakat dari tempat lain akan menyebabkan kebutuhan lahan untuk pemukiman semakin meningkat pesat, namun di sisi lain akan menurunkan luasan lahan untuk sektor pertanian dan perkebunan yang ada di Kecamatan Natar.

Lahan selalu mengalami perubahan dari waktu ke waktu seiring meningkatnya kebutuhan manusia akan lahan. Lahan yang paling sering di beralih fungsi menjadi pemukiman adalah lahan pertanian. Lapatandau dkk (2017) melaporkan bahwa akibat alih fungsi lahan pertanian selain dapat menurunkan produksi tanaman pangan, akan timbul pula permasalahan penurunan kualitas lingkungan yang nantinya akan mengganggu keseimbangan ekosistem. Bahkan alih fungsi lahan akan Jika hal ini terus berlanjut, produksi pangan nasional akan semakin menurun, impor bahan pangan dari luar akan meningkat, dan ketahanan pangan nasional tidak akan pernah tercapai.

Setiap lahan memiliki kerapatan vegetasi yang berbeda beda tergantung dengan jenis penggunaannya. Penelitian ini dilakukan untuk menganalisis perubahan penggunaan lahan dari berdasarkan indeks kerapatan vegetasi pada Kecamatan Natar pada tahun 2002, 2009, dan 2019 dengan penggunaan data masing-masing citra satelit Landsat 7 (tahun 2002 dan 2009) dan 8 (tahun 2019) dengan metode NDVI (Normalized Difference Vegetation Index). NDVI merupakan metode standar dalam membandingkan tingkat kehijauan vegetasi pada data citra satelit. NDVI dapat digunakan sebagai indikator biomassa, tingkat kehijauan relatif, dan untuk menentukan status kesehatan serta kerapatan vegetasi (Lufilah dkk., 2017). Penelitian ini bertujuan untuk mengetahui perubahan penggunaan lahan tahun 2002 dan 2019 pada Kecamatan Natar, Kabupaten Lampung Selatan.

\section{Metode Pelaksanaan}

\section{Waktu dan Tempat}

Penelitian ini dilaksanakan pada tanggal 10 Oktober 2020 sampai 1 Januari 2021. Penelitian ini dilaksanakan di Kecamatan Natar, Kabupaten Lampung Selatan, Provinsi Lampung, Indonesia.

\section{Alat dan Bahan}

Alat yang digunakan pada penelitian ini adalah handphone, laptop dan alat tulis. Sedangkan bahan yang digunakan adalah peta kabupaten Lampung Selatan, citra landsat 7 Kecamatan Natar tahun 2002 dan citra landsat 8 Kecamatan Natar tahun 2019. Software yang digunakan untuk menunjang penelitian ini yaitu Arc GIS 10.3, Microsoft Excel, dan Avenza Maps.

\section{Metode}

Metode yang digunakan untuk mengukur perubahan penggunaan lahan pada penelitian ini adalah metode NDVI (Normalized Difference Vegetation Index). Lufilah dkk (2017) melaporkan bahwa metode ini merupakan metode dengan membandingkan tingkat kehijauan pada vegetasi di suatu lahan dengan menggunakan citra satelit. Semakin banyak daun dan semakin tebal daun pada tumbuhan maka akan sangat berpengaruh pada hasil pantulannya. Jika terdapat lebih banyak dipantulkan dari radiasi panjang gelombang NIR daripada RED, maka tumbuhan pada area tersebut dapat dikatakan padat dan mungkin berupa hutan. Jika terdapat perbedaan yang sangat kecil antara kecerahan panjang gelombang RED dan NIR yang dipantulkan, maka tumbuhan mungkin jarang atau tipis dapat berupa padang rumput atau sawah masa vegetatif. Berdasarkan hal tersebut maka 
nilai NDVI digunakan untuk klasifikasi vegetasi berdasarkan dominasi tumbuhan. Rumus NDVI sebagai berikut:

\section{NDVI = (NIR-RED)/(NIR+RED)}

Keterangan :

1. Pada landsat 8 Nir ( Near Infrared) adalah band 5 dan Red adalah band 4

2. Pada landsat 7 Nir ( Near Infrared) adalah band 4 dan Red adalah band 3

Setelah dilakukannya pengolahan data, data dikelompokkan menjadi 5 kategori yaitu awan, lahan terbuka, lahan semak, lahan vegetasi rendah dan lahan vegetasi sedang. Kemudian dilakukannya pengamatan lapang terhadap 30 titik sampel yang menyebar secara merata di seluruh Kecamatan Natar, yang terdiri 10 titik lahan terbuka, 10 titik vegetasi rendah dan 10 titik vegetasi sedang.

\section{Pelaksanaan Penelitian}

Pelaksanaan penelitian dimulai dengan mengunduh citra Landsat 7 pada tahun 2002 dan citra Landsat 8 pada tahun 2019. Setelah diunduh kemudian masing-masing peta pada tahun-tahun tersebut dilakukan pengolahan data NDVI menggunakan aplikasi Arc GIS 10.3 dengan 5 kategori yaitu awan, lahan terbuka, lahan semak, lahan vegetasi rendah dan lahan vegetasi sedang. Sebelum diolah maka dilakukan terlebih dahulu pemotongan pada peta citra satelit, Pemotongan citra dilakukan untuk membatasi daerah penelitian sehingga pengamatan penelitian hanya berfokus pada Kecamatan Natar serta tidak melewati area kecamatan lain di kabupaten Lampung Selatan.

Selanjutnya luasan pada 5 kategori penggunaan lahan pada peta yang telah diolah dihitung dan data ditabulasi kedalam Microsoft Excel. Setelah itu dilakukan layout pada masing-masing peta. Peta tahun 2019 yang sudah selesai kemudian ditentukan titik sampel pengamatan secara acak yang terdiri dari 10 titik lahan terbuka, 10 titik vegetasi rendah dan 10 titik vegetasi sedang. Pada masing-masing titik dilakukan pengamatan lapang menggunakan bantuan aplikasi Avenza maps guna mengetahui tingkat keakuratan pengolahan data NDVI yang telah dilakukan.

\section{Hasil dan Pembahasan}

\section{Peta Tutupan Lahan Tahun 2002}

Hasil pengolahan data pada peta tutupan lahan Kecamatan Natar tahun 2002 didapatkan bahwa masih terdapat awan, namun relatif kecil yaitu seluas $161 \mathrm{Ha}$, ini di karenakan sebagian lokasi pada kecamatan Natar pada tahun 2002 tertutup oleh awan (Tabel 1) yang di tandai dengan daerah yang berwarna putih pada peta (Gambar 1).

Selanjutnya untuk lahan terbuka dan lahan semak didapat luasan yaitu 2207 dan 4241 Ha (Tabel 1). Pada tahun tersebut, penjualan perumahan masih sangat sedikit. Saat itu perumahan yang sudah ada dan cukup besar hanya terdapat di Desa Hajimena yaitu Perumahan Bataranila dan Perumahan Polri. Pada tahun ini, masih banyak terdapat pepohonan serta masih terdapat banyak perkebunan karet di daerah natar. Ini menyebabkan luasan lahan vegetasi rendah sampai sedang, jauh lebih besar dibanding lahan terbuka dan semak di Kecamatan Natar.

Tabel 1. Luasan berbagai tutupan lahan pada Kecamatan Natar Tahun 2002.

\begin{tabular}{lcc}
\hline \multirow{2}{*}{ Tutupan Lahan } & \multicolumn{2}{c}{ Luasan Area } \\
& Ha & $\mathbf{0}$ \\
\hline Awan & 161 & 0,7 \\
Lahan Terbuka & 2270 & 9,3 \\
Lahan Semak & 4241 & 17,9 \\
Lahan Vegetasi Rendah & 13816 & 58,4 \\
Lahan Vegatasi Sedang & 3233 & 13,7 \\
\hline Total & $\mathbf{2 3 6 5 8}$ & $\mathbf{1 0 0}$ \\
\hline
\end{tabular}

Tabel 2. Luasan berbagai tutupan lahan pada Kecamatan Natar Tahun 2002.

\begin{tabular}{lcc}
\multicolumn{1}{c}{ Tutupan Lahan } & \multicolumn{2}{c}{ Luasan Area } \\
& Ha & $\mathbf{0}$ \\
\hline Awan & 2472 & 10,8 \\
Lahan Terbuka & 9574 & 42 \\
Lahan Semak & 4768 & 20,1 \\
Lahan Vegetasi Rendah & 5910 & 25,9 \\
Lahan Vegatasi Sedang & 119 & 1,2 \\
\hline Total & $\mathbf{2 2 8 4 3}$ & $\mathbf{1 0 0}$ \\
\hline
\end{tabular}

Hasil pengolahan data pada tabel peta tutupan lahan Kecamatan 2019 didapati hasil bahwa lahan terbuka (Tabel 2) paling mendominasi dibanding luasan tutupan lahan lainnya yaitu seluas $9574 \mathrm{Ha}$. Hal ini berbeda pada jauh dibanding data tahun 2002 (Tabel 1) dimana luasan tutupan lahan didominasi oleh lahan vegetasi rendah hingga sedang. Pada Tahun 2019 dapat dilihat bahwa walaupun luasan lahan vegetasi rendah cukup tinggi yaitu seluas $5910 \mathrm{Ha}$, namun lahan semak juga sangat tinggi yaitu seluas $4768 \mathrm{Ha}$. Pada tahun 2019 ini, luasan lahan vegetasi sedang sangat rendah yaitu hanya berkisar $119 \mathrm{Ha}$ 


\section{PETA TUTUPAN LAHAN KECAMATAN NATAR, INDONESIA}
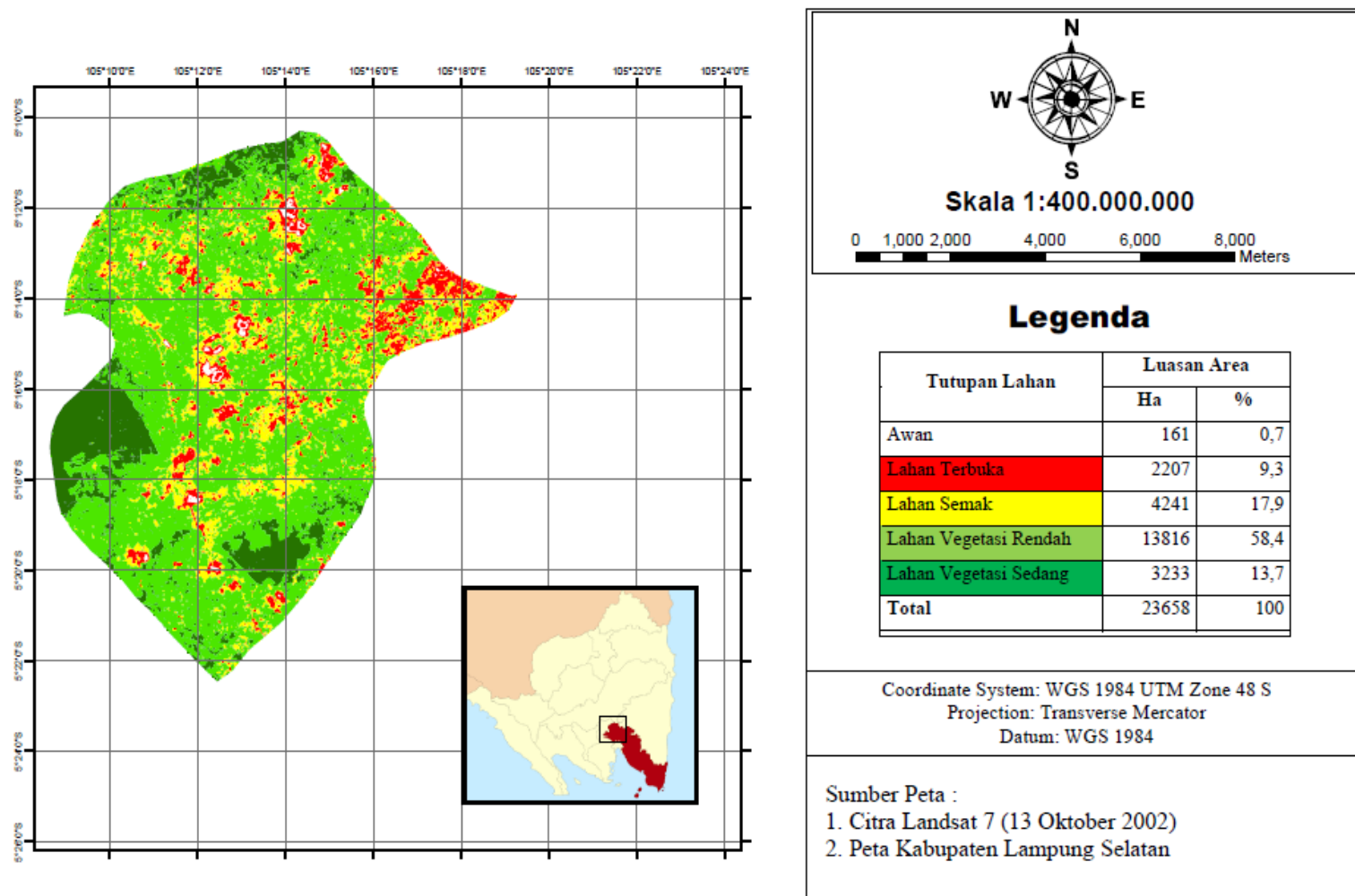

Gambar 1. Peta Tutupan Lahan Kecamatan Natar Tahun 2002.

\section{PETA TUTUPAN LAHAN KECAMATAN NATAR, INDONESIA}
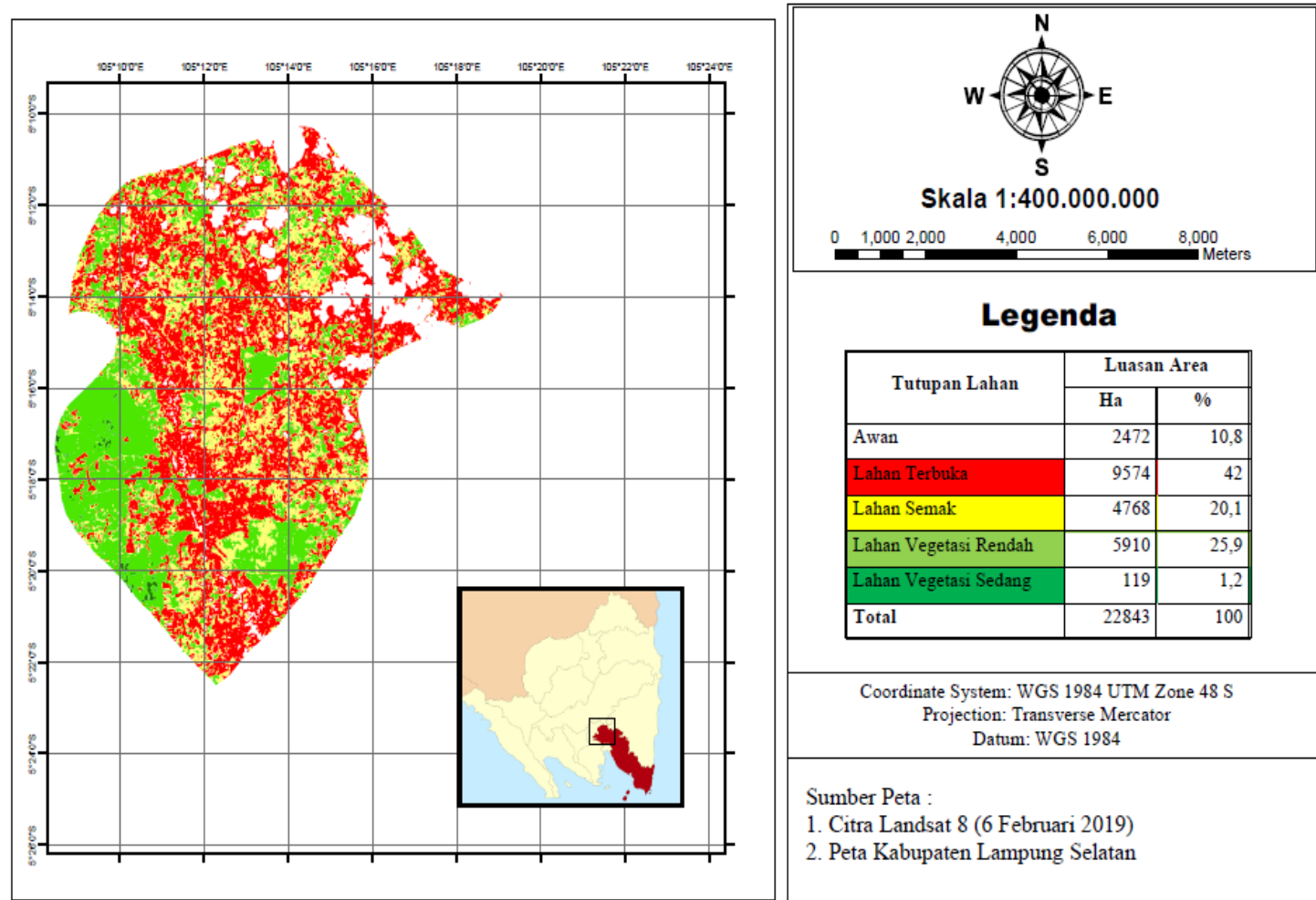

Gambar 2. Peta tutupan lahan Kecamatan Natar Tahun 2019 
Peningkatan lahan terbuka ini diawali oleh proyek perluasan Bandara Raden Inten II. Hal ini diperkuat dengan sejarah Bandara Raden Inten II, dalam laporan Basmalda (2018) dijelaskan bahwa proyek perluasan Bandara Raden Inten II dimulai sejak tahun 2004 yaitu dimulai dengan proyek perluasan landasan pacu pesawat dan masih terus berlangsung hingga sekarang. Dengan adanya proyek perluasan, lahan disekitar Bandara yang sebelumnya berupa hutan kayu mulai ditebang untuk perluasan landasan pacu pesawat.

Perluasan Bandara mengundang banyak masyarakat baik dari Kecamatan Natar maupun luar kecamatan untuk membeli tanah dan membangun rumah di sekitar Bandara. Semenjak tahun tersebut, mulai banyak bermunculan agen tanah dan perumahan disekitar Desa Branti Raya hingga Desa Natar. Selain itu, semenjak tahun 2006 terdapat pembanguan salah satu Mall yang cukup besar (pada saat itu) di Desa Merak Batin. Ketika Mall ini dibangun, Desa Negara Ratu dan Desa Tanjung Sari yang Awalnya sepi mulai dilirik agen tanah dan perumahan. Hal ini yang mengakibatkan pada tahun tersebut, perubahan daerah tutupan lahan sudah cukup signifikan.

Peningkatan lahan terbuka yang sangat drastis terjadi pada tahun 2014, setelah dikeluarkan peraturan pemerintah No. 100 tahun 2014 tentang Percepatan Pembangunan Jalan Tol di Sumatera. Akibat peraturan ini, banyak lahan pertanian, perkebunan dan perumahan warga yang dilewati jalur tol dialihfungsikan. Adanya jalan tol ini membuat Desa yang awalnya sepi seperti Desa Krawang Sari, Desa Tanjung Sari,Desa Pancasila dan Desa Bandarejo karena desa ini berada tepat didekat jalan tol, perlahan jalan masuk ke Desa ini mulai diperbaiki. Kemudahan akses ini mengundang banyak agen tanah dan perumahan ke Desa ini sehingga Desa yang awalnya tertinggal menjadi Pemukiman Padat Penduduk.

Selain itu di Kecamatan Natar mulai banyak karet, kelapa dan sawit yang tidak produktif. Sehingga banyak masyarakat yang menebang pohon tersebut dan memanfaatkan lahan untuk dijadikan lahan pertanian atau bahkan dijual ke agen perumahan. Pada Tahun 2015, ketika Bapak Zainudin terpilih menjadi Bupati Lampung Selatan, mulai muncul wacana untuk memecah Kecamatan Natar menjadi Kabupaten Mandiri. Akibat Wacana ini, semakin banyak perumahan dibangun dan alih fungsi lahan menjadi semakin tinggi.

Pada saat pengecekan lokasi di lapangan dari 30 titik yang diambil dari Peta tutupan lahan Kecamatan Natar Tahun 2019 (Gambar 3), 10 titik yang merupakan lahan terbuka terdiri dari pemukiman penduduk, pasar serta persawahan. Pada lahan semak, 10 titik akurat dan menunjukan penggunaan lahan sebagai perkebunan warga dengan sedikit pohon berkayu serta memiliki jarak yang tidak teratur dan berjauhan. Pada lahan vegetasi rendah, dari 10 titik hanya 9 titik yang akurat. Ini dikarenakan 1 titik pengamatan lahan vegetasi rendah dulunya merupakan kebun tanaman jati dan sengon. Namun saat pengamatan di lapang, pohon tersebut sudah ditebang dan beralih fungsi menjadi lahan terbuka. 9 titik lahan vegetasi rendah tersebut terdiri dari tanaman sawit, cokelat dan karet. Dari 30 titik, terdapat 29 titik yang akurat sehingga tingkat keakuratan peta tutupan lahan Kecamatan Natar tahun 2019 sekitar 96,7\%.

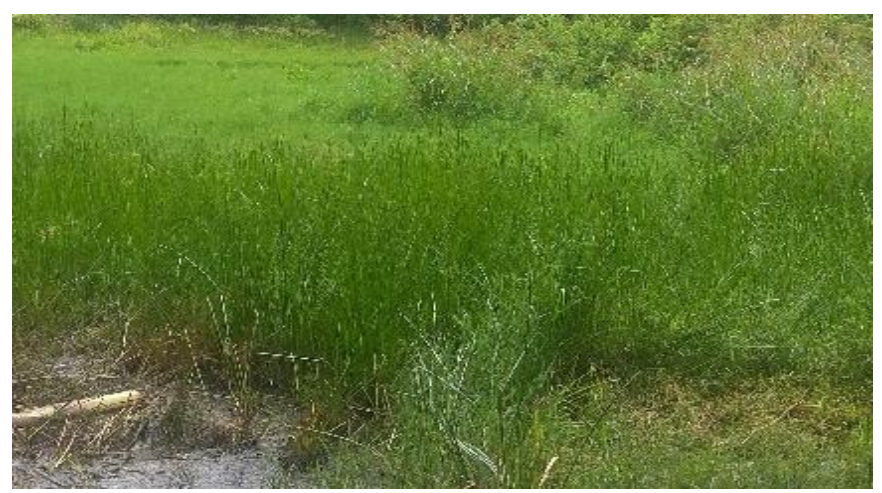

Gambar 3. Titik Sampling Lahan Terbuka yang Menunjukan Areal Sawah

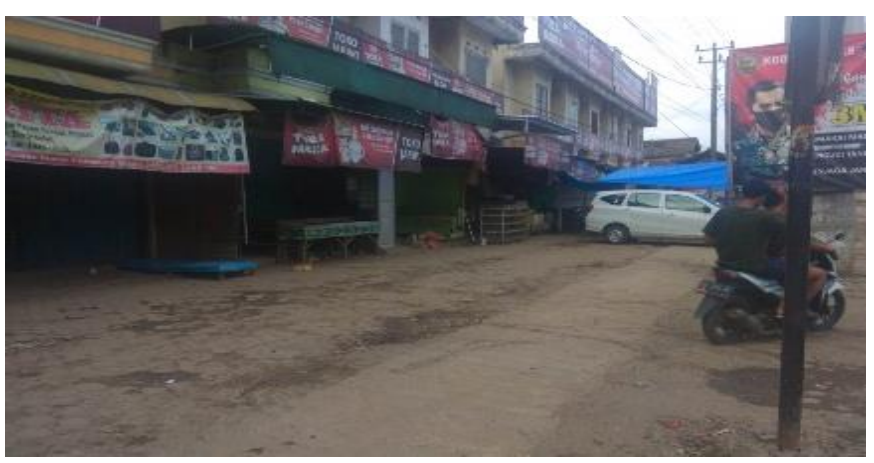

Gambar 4. Titik Sampling Lahan Terbuka yang Menunjukan Pasar

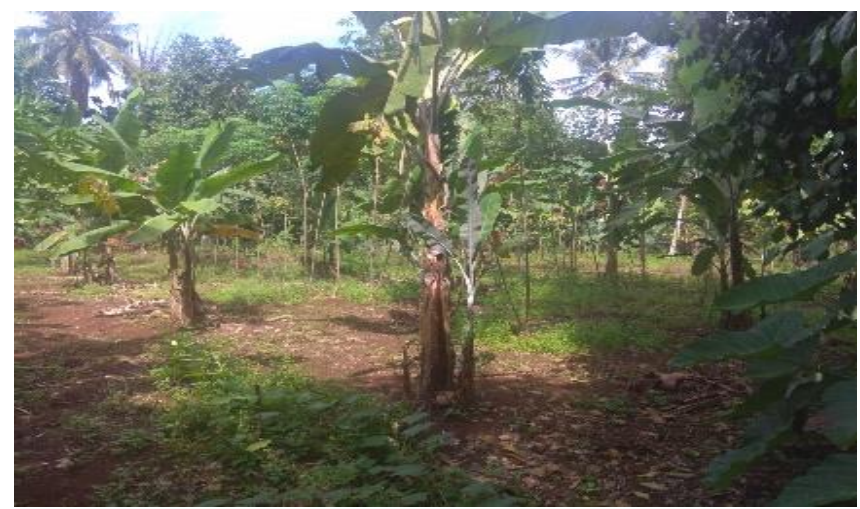

Gambar 5. Titik Sampling Lahan Semak yang Menunjukan Perkebunan Pisang Warga 


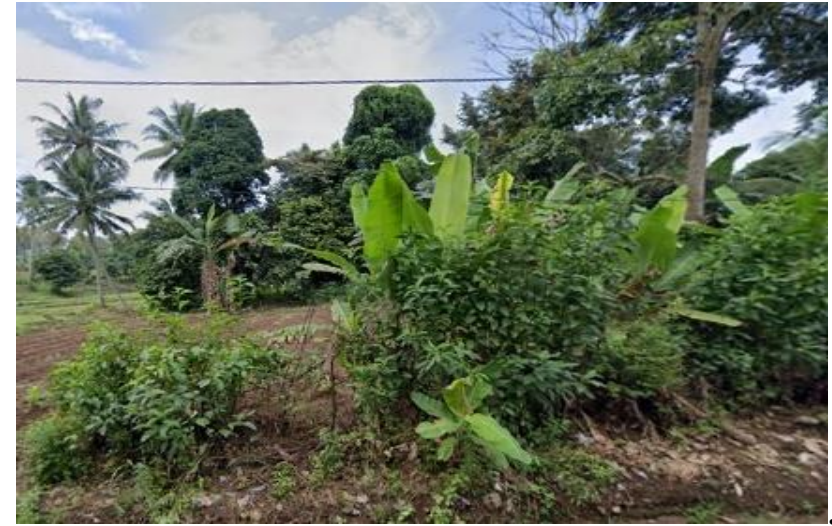

Gambar 6. Titik Sampling Lahan Semak yang Menunjukan Lahan ditanami Acak

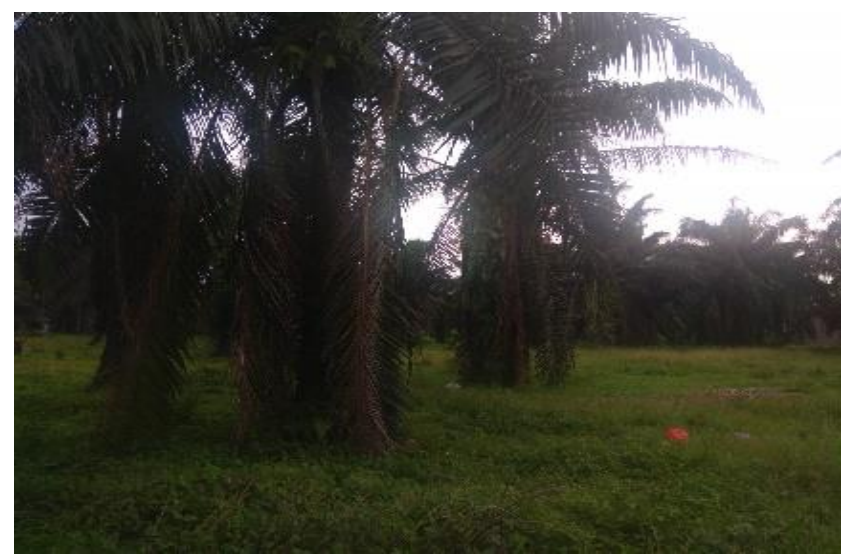

Gambar 7. Titik Sampling Lahan Vegetasi Rendah yang Menunjukan Perkebunan Sawit

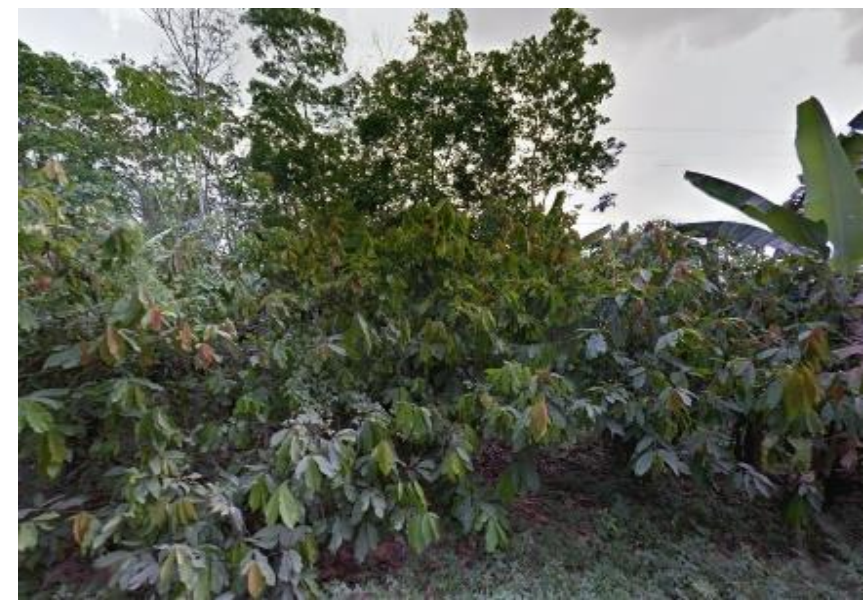

Gambar 8. Titik Sampling Lahan Vegetasi Rendah yang Menunjukan Perkebunan Cokelat

Berdasarkan data yang telah diperoleh dapat dilihat terjadi peningkatan jumlah penduduk akan meningkatkan jumlah pembukaan lahan yang dilakukan oleh masyarakat guna memenuhi kebutuhan akan tempat tinggal. Hal ini dapat dilihat dari bertanbahnya lahan terbuka sebanyak 32,7\% dari tahun 2002 karena merebaknya pemukiman. Oleh karena itu sangat perlu peran aktif pemerintah dalam penekanan jumlah penduduk agar kegiatan pembukaan lahan baru umtuk pemukiman diminimalisir.

Hal tersebut dilakukan untuk meminimalisir alih fungsi lahan yang kerap terjadi, yang mana alih fungsi lahan ini akan menyebabkan terjadinya hilangnya lahan-lahan pertanian sehingga nantinya akan terjadi kekurangan bahan pangan. Dapat dilihat bahwa pada tahun 2019, dibandingkan dengan tahun 2002 lahan vegetasi rendah dan sedang menurun masing masing sebanyak $32,5 \%$ dan $12,5 \%$.

Selain itu pemerintah harus mengetatkan peraturan lingkungan terkait lahan lahan yang boleh dialihfungsikan maupun yang tidak. Jika pertumbuhan penduduk menjadi tidak terkendali, alih fungsi lahan pertanian meningkat, maka akan mustahil Indonesia dapat mewujudkan ketahanan pangan Nasional

\section{Kesimpulan}

Peningkatan jumlah penduduk yang disebabkan berbagai faktor dapat menyebabkan peningkatan alihfungsi lahan menjadi lahan terbuka yang diisi oleh pemukiman penduduk. Pada tahun 2002 nilai lahan dengan vegetasi rendah sampai sedang masih menjadi yang paling dominan. Namun, pada tahun 2019 lahan terbuka menjadi sangat luas bahkan lebih luas dari lahan vegetasi rendah hingga sedang. Lahan terbuka di Kecamatan Natar pada tahun 2019 meningkat sebanyak $32,7 \%$ dari tahun 2002, sebaliknya lahan vegetasi rendah dan sedang menurun masing masing 32,5\% dan $12,5 \%$ sejak tahun 2002. Perubahan lahan yang tinggi ini dikarenakan tingginya tingkat pembangunan di Kecamatan Natar dalam 15 tahun terakhir. Tingginya tingkat pembangunan mengundang berbagai masyarakat baik dari dalam Kecamatan Natar maupun luar Kecamatan untuk berinvestasi mulai dari membeli tanah maupun membangun rumah sehingga menyebabkan peningkatan alih fungsi lahan yang sangat tinggi. Berdasarkan hasil turun lapang, dari 30 titik, terdapat 29 titik yang akurat sehingga tingkat keakuratan peta tutupan lahan Kecamatan Natar tahun 2019 sekitar 96,7\%.

\section{Daftar Pustaka}

Badan Pusat Statistik. (2015). Tabel Luas Wilayah dan Jumlah Penduduk menurut Kecamatan di Kabupaten Lampung Selatan. Badan Pusat Statistik. Lampung Selatan.

Basmalda, A. R. (2018). Perancangan Aplikasi Pembuatan PAS Bandar Udara Radin Inten II. Laporan Praktik Kerja Lapang. Program Studi Informatika Universitas Teknokrat Indonesia. 
Lapatandau, Y. A., Rumagit, G. A. J., dan Pakasi, C.B.D. (2017). Alih Fungsi Lahan Pertanian di Kabupaten Minahasa Utara. J. Agri-Sosio Ekonomi Unsrat. 13(2A):1-8.

Lufilah, S.N., Makalew, A. D.N., dan Sulistyantara, B. (2017). Pemanfaatan Citra Landsat untuk Analisis Indeks Vegetasi di DKI Jakarta. Jurnal Lanskap Indonesia. 9(1):73-80.

Peraturan Presiden (PP) No. 100 Tahun 2014 tentang Percepatan Pembangunan Jalan Tol di Sumatera

Purnomo, J.S.. (2018). Kecamatan Natar Dalam Angka. Badan Pusat Statistik. Lampung Selatan 